\title{
Applications of Geospatial Technologies in Land Capability Classification of a Macro Watershed
}

\author{
Syed Hamim Jeelani, Durga Chaitanya Kumar Jagarapu, M Lingadevaru' and \\ Asim Rifa Ur Rahman \\ Department of Civil Engineering, Koneru Lakshmaiah Education Foundation, \\ Deemed to be University, Guntur-522502, India \\ ${ }^{1}$ Department of Geology, Central University of Karnataka, Kadaganchi, Kalaburagi -585 367, India \\ ${ }^{2}$ Department of Civil Engineering, National Institute of Technology Andhra Pradesh, Tadepalligudem- 534 101, India \\ E-mail: hamim.syed@gmail.com
}

\begin{abstract}
This study deals with the estimation of the land capability and generation of different classes on Chevella watershed area, Ranga Reddy dist., Telangana state. The land capability was estimated with the land capability classification technique where the land is classified into 8 classes based on the characteristics associated with each of the class on certain parameters that affect the soil and the water as well, which are the two most important factors of the cultivation. The classes of land capability are broadly classified into 2 i.e., cultivable and noncultivable. Based on the land capability, the land resource development Plan was generated which give the in-site of the crops and the precautions that need to be grown in the region which was compared to 3 classes. This land is suitable for occasional cultivation in rotation with hay or pasture, or orchards protected by permanent cover crops. Special precautions suggested in accordance to IS Code for conservation of rainfall to utilize for irrigation, conversion of land to pasture or grazing lands the regions.
\end{abstract}

Keywords: Land capabilitym, Macro watershed, Capability, Cultivation, Mobile mapping, GIS platform

The soil and water conservation method are all recommended based on the capability of the land and enlists the natural limitations of the soil and water. The land capability is important to estimate because of the increasing growth of the population (Singh 2000). As its increase will lead to more pressure on the land thus, making the optimum utilization of the land (Gangopadhyay et al 2010). Therefore, being present at the field or the location at which the capability is to be estimated becomes time consuming and tedious process (Mohan et al 2007). To estimate the Land capability potential index, one needs to integrate hydrology, hydraulics, land-surface elevations, and soil permeability (Singer 2020). The index integrates the above-mentioned fundamental factors that determine suitability of land for different kinds of utilization and provide a useful mechanism to guide land-management decisions (Jacobson et al 2007). In order to get better results at a finer resolution the technique used by Tideman (2007), Solanki and Bishnoi (1995) the Land capability is categorized into 8 classes and estimating the capability will be used. These 8 classes are broadly classified into 2 and each one of them is assigned a specific colour (Kumar et al 2019). LUCC is made on the capability of land for agricultural production on permanent basis, under specified management practices to sustain the productivity (Prince et al 2009). According to this definition two considerations are made in suggesting LUCC, one is agricultural production from land and the other is negative weightage are considered as natural hazards (Sujatha et al 2019). The present study is carried out for determining the procedure for automatic generation of the land capability maps from the various thematic maps and collateral information. Therefore, to achieve the desired land capability map, the study has been carried out with objectives to know the land capability classification alongside the slope, erosion, and depth of Chevella macro watershed area and creating land capability classification model to show the land capable for cultivation and to prepare land resource development plan of the area based on land capability.

\section{MATERIAL AND METHODS}

Study area: The study was conducted on a Macro watershed, Chevella Block, Ranga Reddy District Telangana state. The area lies in between $17.3067^{\circ} \mathrm{N}$ Latitude and $78.1353^{\circ} \mathrm{E}$ Longitude (Fig. 1). The macro watershed has area of about 5836 hectares, the inhabited villages are 36 . This macro watershed has 525 cultivators, 210 agricultural labourers, 15 household industry workers and 100 other workers (Census 2011). The major crops that are cultivated in this region are cotton \& green gram, vegetables, red gram. This region has gone through a change in the type of crops 
that are grown due to the change in weather conditions of the regions. The terrain is undulating. These undulations are barren with some shrubs here and there on them. The groundwater level is very low at 200 to 500 feet whereas the wells are dry from the past 2 years. Moreover, the fluoride content in the soil has also increased over the period. This village is also a part of Integrated Watershed Management Project - IWMP launched by the Telangana Government for the restoration of all the check dams and streams that are present in the region. Under this mission the water of all the identified check dams will be used for irrigation in the area surrounding it.

Land capability classification map: Land capability classification map was made considering the basic 4 parameters and other local limitations that effects the land capability were also considered and based on the combination of the characteristics of each parameter the respective land capability class was given. The division of the parameters are denoted with a particular symbol which represents a specific characteristic (Table 1).

Classification of land capability: Each of these classes has specific characteristics associated with them and there are four factors that are considered for the estimation of Land capability each with a defined symbol. They are mainly slope, soil texture, erosion and soil depth. The first step of capability classification is the estimation of mapping units and to the grouping of one or more than one individual soil mapping units which have same potentials. The equation of mapping units is given by:

(Soil series - texture of soil - soil depth) / (Land slope erosion)

Mapping units are needed as the units and the values for each of the factors is considered in the estimation of land capability is different and cannot be considered without normalizing the data of the factors.

Soil depth: Soil depth influences the crop that is grown, crop yield and the amount of soil water. The data for soil depth was obtained from the field with the help of the local people

Table 1. Land capability class

\begin{tabular}{lcc}
\hline Broad class & Class & Colour \\
\hline Land fit for cultivation & I & Light colour \\
& II & Yellow \\
III & Red \\
IV & Blue \\
Land Not suitable for cultivation & V & Dark green \\
& VI & Orange \\
& VII & Brown \\
& VIII & Purple \\
\hline
\end{tabular}

through Participatory Rural Appraisal (PRA) for different point locations and then this point data was interpolated for the complete area. The depth of the soil was classified according to the land capability class where it ranges from more than $90 \mathrm{~cm}$ to less than $7.5 \mathrm{~cm}$ (Table 2).

Soil texture: The data for the soil texture was obtained from the Mandal Agricultural office from the soil health cards for the region which were then checked with through PRA and the soil texture map for the region was generated. The texture of the soil was classified based on the land capability class (Table 3).

Slope: To find the slope of the area used the contours at the interval of $5 \mathrm{~m}$ to generate the DEM i.e., Digital Elevation Model and then the slope of the study area was estimated. The slope of the area was also classified based on the specific characteristics associated with each land capability class (Table 4).

Erosion: The information of the erosion was collected on the field with the help of local people through PRA and the official who were working in the area. The degree of erosion was also classified based on the land capability classification class (Table 5). First, watershed shape file was collected and then later in QGIS grids/centroids points were created before going to the field. Collection of data in PRA (Public Rural

Table 2. Soil depth class after E.M Tide man, 1996

\begin{tabular}{lllc}
$\begin{array}{l}\text { Soil depth } \\
(\mathrm{cm})\end{array}$ & Class symbols & Description & $\begin{array}{c}\text { Land capability } \\
\text { class }\end{array}$ \\
\hline$>90$ & $\mathrm{~d} 5$ & Very deep & $\mathrm{I}$ \\
$45-90$ & $\mathrm{~d} 4$ & Deep & II \\
$22.5-45$ & $\mathrm{~d} 3$ & Moderately deep & III \\
$7.5-22.5$ & $\mathrm{~d} 2$ & shallow & IV \\
$<7.5$ & $\mathrm{~d} 1$ & Very shallow & VI, VII \\
\hline
\end{tabular}

Table 3. Soil texture

\begin{tabular}{lc}
\hline Texture class & Symbol \\
\hline Land capability class I & \\
Sandy loam & $\mathrm{SI}$ \\
Clay loam sandy & $\mathrm{L}$ \\
Clay loam silt & $\mathrm{Cl}$ \\
Silty loam & $\mathrm{SCL}$ \\
Clay loam & $\mathrm{Si} \mathrm{sil} \mathrm{sicl}$ \\
Land capability class II & \\
Silty clay & $\mathrm{Sic}$ \\
Sandy clay & $\mathrm{Sc}$ \\
Clay & $\mathrm{C}$ \\
Land capability class III & \\
Loamy sand Clay & Is C \\
Land capability class IV & \\
Sand & $\mathrm{S}$ \\
\hline
\end{tabular}


Appraisal) with help of ODK was done. Interpolation and IDW was done using QGIS. Raster layers of texture, depth and erosion were created and then the SRTM - DEM was downloaded from Bhuvan website on which slope and all raster files were converted into vector and finally smooth layering was done in GRSS 7.2.2. That smooth vector layers were classified as per the land capability class wise and prepared layout for map of each layer therefore, the final class of Land Capability Class was made. For intersection we used formula of map unit:

Mapping unit: soil texture - soil depth / Land slope - soil erosion

Software: ArcGIS, Earth Explorer, QGIS (Quantum GIS), GRASS 7.2.2 (Geographic Resource Analysis Support

Table 4. Slope class

\begin{tabular}{lclc}
$\begin{array}{l}\text { Slope } \\
\text { class }\end{array}$ & $\begin{array}{c}\text { Slope range } \\
(\%)\end{array}$ & Description & $\begin{array}{c}\text { Land capability } \\
\text { class }\end{array}$ \\
\hline A & $0-1$ & Nearly Level & I \\
B & $0-3$ & Very Gently sloping & II \\
C, D & $3-5$ & Gently sloping & III \\
& $5-10$ & Moderately sloping & \\
E, F & $10-15$ & Strongly sloping & IV \\
G & $15-25$ & Moderately steep to steep & VI \\
H & $25-33$ & Steep & VII \\
I & $33-50$ & Very steep & VIII \\
\hline
\end{tabular}

Table 5. Erosion class

\begin{tabular}{llc}
$\begin{array}{l}\text { Erosion class } \\
\text { symbol }\end{array}$ & $\begin{array}{c}\text { Description (degree of erosion) } \\
\text { class }\end{array}$ \\
\hline E1 & Up to $25 \%$ A horizon is lost & I \\
E2 & Up to $25 \%$ A horizon is lost & II \\
E3 & $50-75 \%$ A horizon is lost & III \\
E4 & $\begin{array}{l}\text { A horizon is lost and B horizon is } \\
\text { exposed }\end{array}$ \\
E5 & $25-75 \%$ B horizon is lost & IV \\
E6 & $25-75 \%$ B horizon is lost & $\mathrm{V}$ \\
\hline
\end{tabular}

System) ODK (Open Data Kit).

All the above-mentioned factors were considered and the mapping units of each of the class were estimated based on the following notation:

Texture of soil - soil depth / Land slope: Based on the mapping units the land was classified into different Land Capability Classes with reference to the Table 6. The capability class will be the highest number allotted to any of the parameters and the other local limitation will suffix the roman Land Capability Class no. Thus, the Capability of the land of the macro watershed region was estimated. The Land capability class no. $V$ has the similar characteristics as that of land capability class I except for a few limitations of stoniness and wetness. The classes $\mathrm{V}$ and above have no mention about the soil texture as these classes fall under the noncultivable land category.

\section{RESULTS AND DISCUSSION}

Land capability classification map: The soil depth of the region ranged from 0 to 121.9 centimeters as the region has undulating terrain. There was no soil on the hillocks with highest depth recorded near the areas surrounding the reservoirs. Soil depth modifies the rooting system of plants which reflects on crop growth and yield the amount of soil water. The soil depth of the region was classified into 4 Land Capability Classes based on the classification criteria mentioned above in the methodology. The color representing each of the class is the standard color assigned to them as mentioned in the literature review. The 4-soil depth land capability classes that were present in the region were I, II, III, and IV (Table 7). Class I is area covered with $214.46 \mathrm{Kms}$ and its shows in the Class I with more than $90 \%$, class II shows with 45 to $90 \%$, Class III with 22.5 to 45 and Class IV with 22.5 to $7.5 \%$ (Fig. 2).

Soil texture: Soil textures are of great importance in the land use capability classification as it influences the water holding capacity, permeability, drainage, runoff etc. This region has only two different types of soil texture i.e., sandy clay loam

Table 6. Land capability parameters

\begin{tabular}{lclcl}
\hline $\begin{array}{l}\text { Land capability } \\
\text { classification }\end{array}$ & Soil depth & Soil texture & Slope range & Degree of erosion \\
\hline I & $>90$ & Sandy loam clay loam silty clay & $0-1$ & Up A horizon is lost to 25\% \\
II & $45-90$ & Silty clay sandy clay clay & $1-3$ & Up to A horizon is lost o 25\% \\
III & $22.5-45$ & Loam sand clay & $3-5$ & $50-75 \%$ A horizon is lost \\
IV & $7.5-22.5$ & Sand & $5-10$ & \\
& & & $10-15$ & A horizon is lost and B horizon is exposed \\
V & $<7.5$ & - & $15-25$ & \\
VI & $<7.5$ & - & $25-28$ & $25-70 \%$ B Horizon Lost \\
VII & $<7.5$ & - & $25-33$ & $25-75 \%$ B horizon is lost \\
\hline
\end{tabular}


and clay loam. Most of the area is covered with sand clay loam and the areas near the reservoirs have the clay loam (Table 8, Fig. 3).

Slope: This region has an undulating terrain because of which there is the variation in the soil depth. In the same way there is a lot of variation in the slope of the region of the watershed area. The slope of the region ranges from 0 to $40 \%$ with highest near the hillocks and minimum in the central
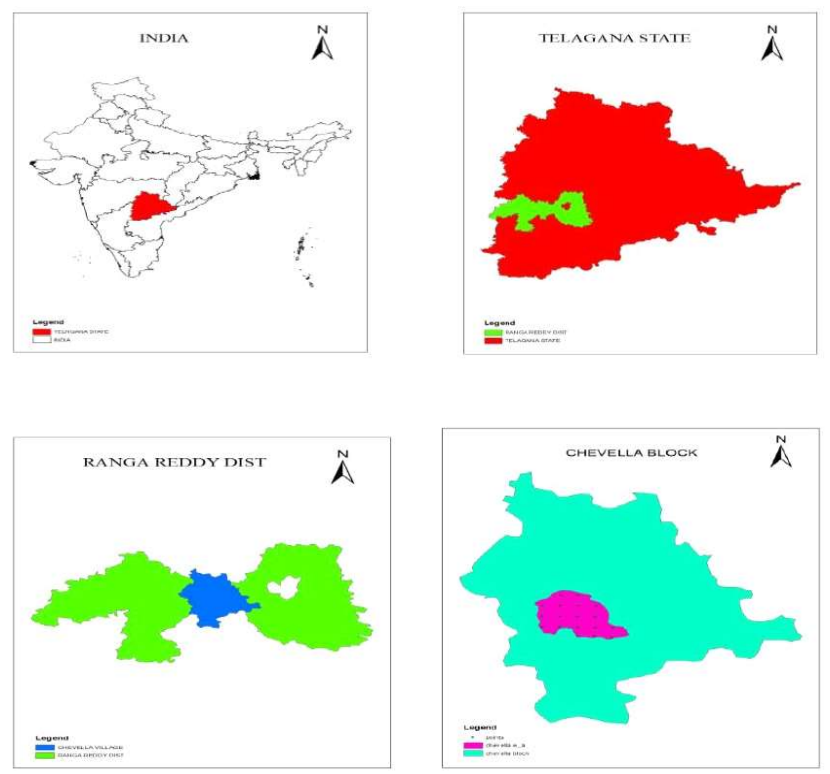

Fig. 1. Location map of study area

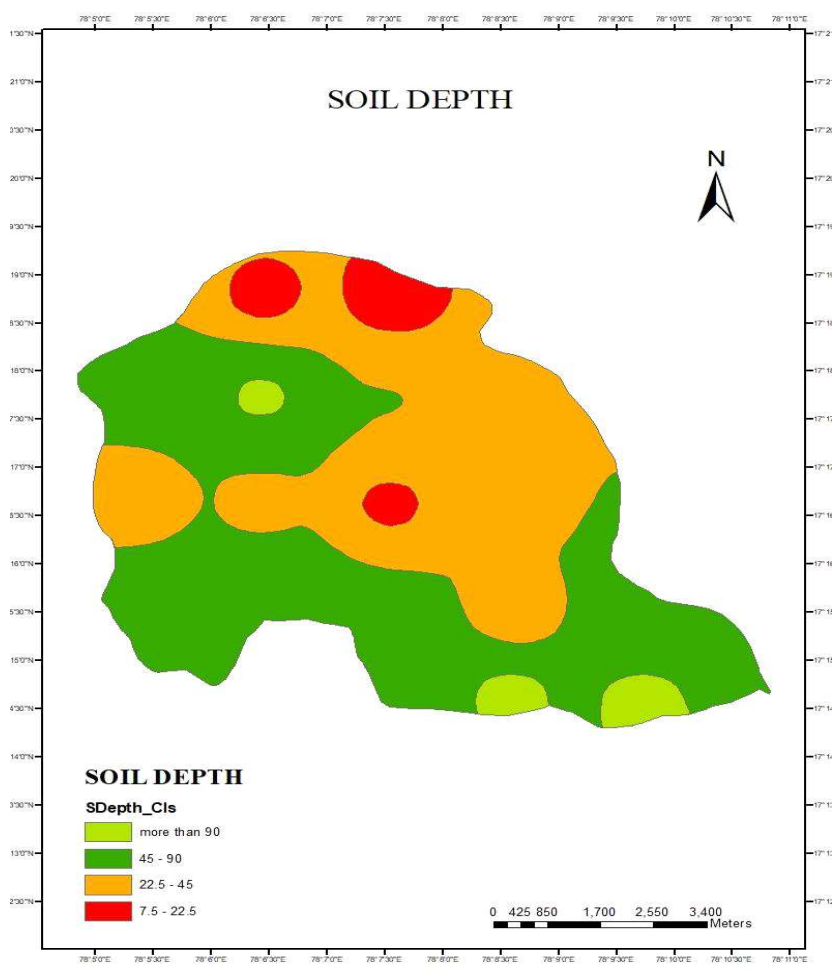

Fig. 2. Soil depth region of the village. Soil and water losses from an area of the watershed are influenced by length and degree of slope. These factors influence the land capability classification. Accordingly various modified slope classes, arranges and description with suggested capability classes. The slope of the region was classified into 5 Land Capability Classes based on the classification criteria mentioned above in the methodology (Table 9, Fig. 4).

Erosion: The erosion was estimated by visual interpretation of the region. But to decide, the other parameters like the slope and terrain conditions were decided after deciding the values based on above three parameters and it was shown as a suffix to each class. Based on the other above estimated parameters the mapping units were derived which is based on the equation mentioned in the methodology and the parameter with the highest Land Capability Class value is allotted to that region. Assessment of soil erosion is made by ocular estimate which to some extent depends on the experience and personal judgment. While it is easy to pinpoint the menace of erosion in case of a very specific situation (Fig. 5).

Land capability class: Based on the above estimated parameters the mapping units were derived which is based on the equation mentioned in the methodology and the parameters with the highest Land Capability Class value is allotted to that region (Table 11, Fig. 6).

Land capability mapping units: The study that was conducted gave the information about various conditions and

Table 7. Area under each soil depth class

\begin{tabular}{lcc}
\hline Soil depth $(\mathrm{cm})$ & Land capability class & Area (ha) \\
\hline More than 90 & I & 214.46 \\
$45-90$ & II & 3465.98 \\
22.5 to 45 & III & 268884 \\
7.5 to 22.5 & IV & 314.24
\end{tabular}

Table 8. Area under each soil texture class

\begin{tabular}{lcc}
\hline Soil texture & Land capability class & Area (ha) \\
\hline Sandy clay loam & I & 5127.96 \\
Loamy sand, clay & II & 89.67 \\
Silty clay, sandy clay & III & 205.01 \\
\hline
\end{tabular}

Table 9. Area under each slope class

\begin{tabular}{lcc}
\hline Slope (I \%) & Land capability class & Area (ha) \\
\hline $0-1$ & I & 2473.97 \\
$1-3$ & II & 2473.97 \\
$3-10$ & III & 3835.63 \\
$10-25$ & IV & 9.18 \\
$25-33$ & VI & 4.32 \\
\hline
\end{tabular}




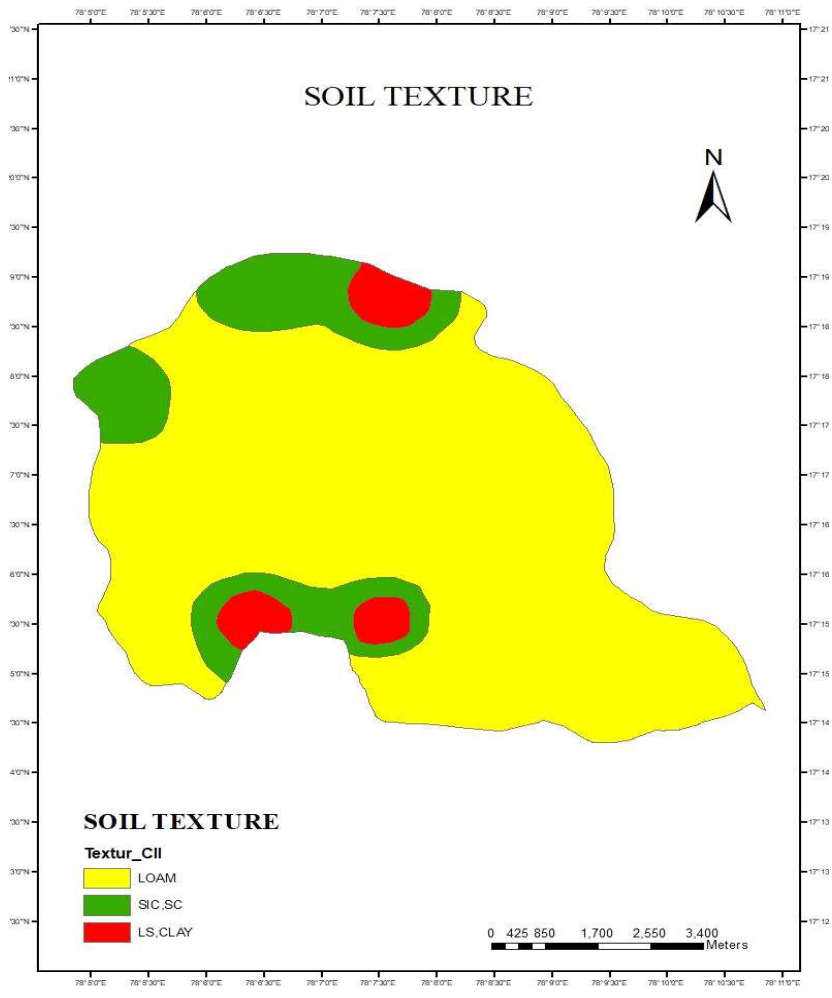

Fig. 3. Soil texture of Chevella block

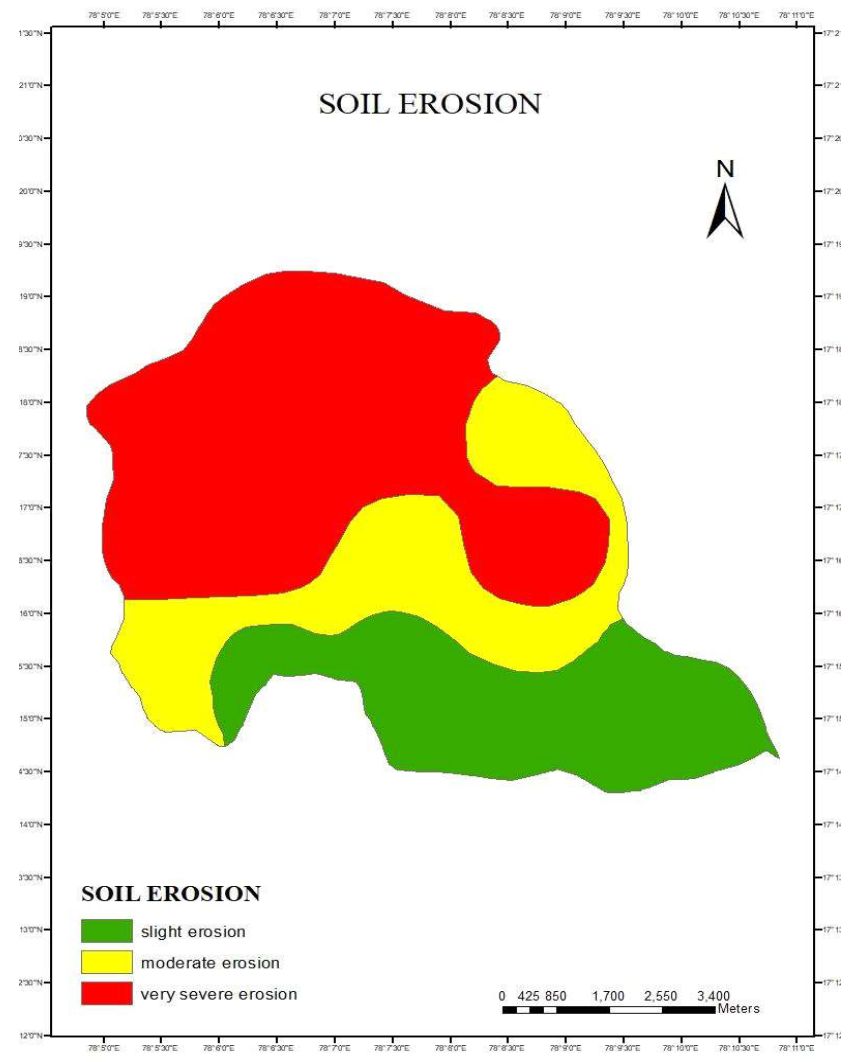

Fig. 5. Soil erosion of Chevella block
Table 10. Area under each erosion class

\begin{tabular}{lc}
\hline Land capability class & Area (ha) \\
\hline Slight erosion & 1671.26 \\
Moderate erosion & 1564.02 \\
Severe erosion & 3083.51 \\
Very severe erosion & 129.60 \\
\hline
\end{tabular}

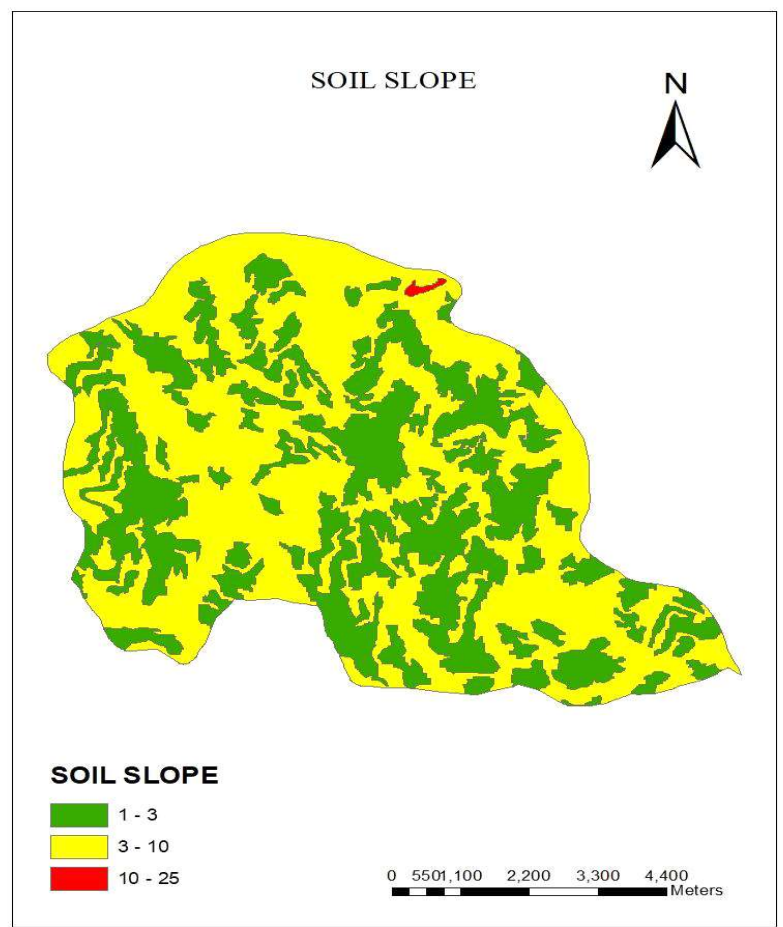

Fig. 4. Soil slope of Chevella block

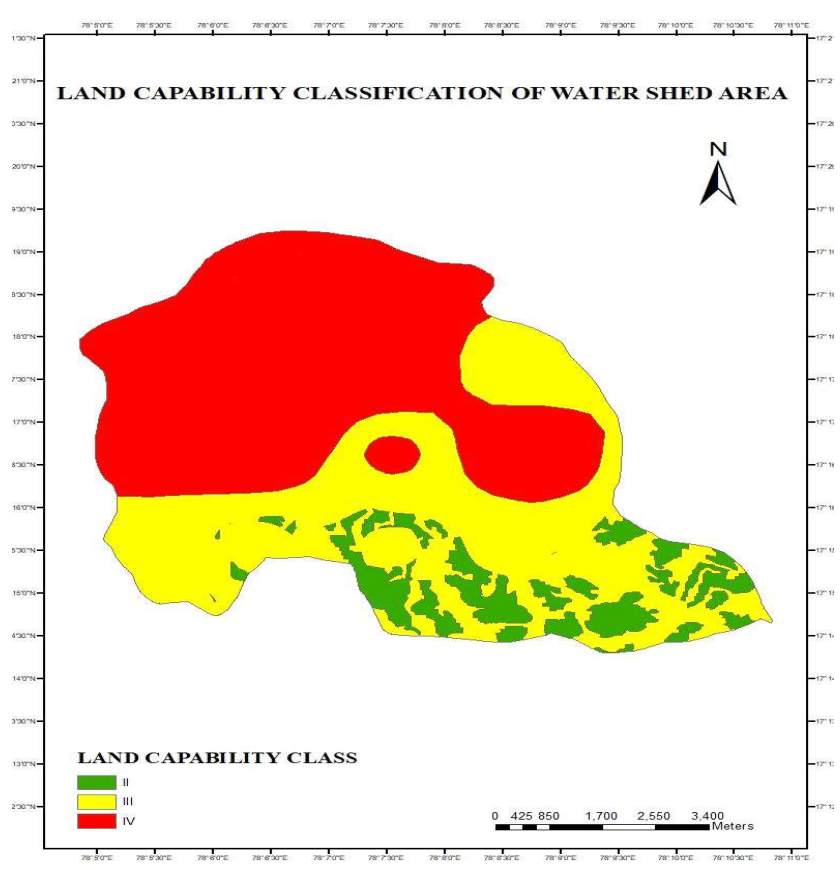

Fig. 6. Land capability classification of watershed area of Chevella block 
the kind of problems associated with the agricultural practices that are prevailing in the village. The observations are collected as required under item of the mapping units are built as below:

$$
\text { Mapping units: } \begin{gathered}
\begin{array}{c}
\text { Soil series-texture of top soil } \\
\text {-effective soil depth }
\end{array} \\
\text { Land slope-erosion hazard }
\end{gathered}
$$

These mapping units are derived following rating and delineated on survey map for land capability classification. Boundaries are marked to separate areas belonging to different mapping units.

$$
\text { Mapping units: } \frac{\mathrm{KT}-\mathrm{c}-\mathrm{d} 5}{\mathrm{~B} \text { e1 }}
$$

$\mathrm{KT}$ - soil series, c - clay (texture), d5 - soil depth more than $90 \mathrm{~cm}, \mathrm{~B}-1-3 \%$ land slope, e 1 - sheet erosion

This study had certain elements or techniques that were included in the study for the better results and approach towards the work. They are as follows:

Table 11. Area under each land capability class

\begin{tabular}{lc}
\hline Land capability class & Area (ha) \\
\hline II & 596.13558 \\
III & 2510.41632 \\
IV & 3014.92911 \\
\hline
\end{tabular}

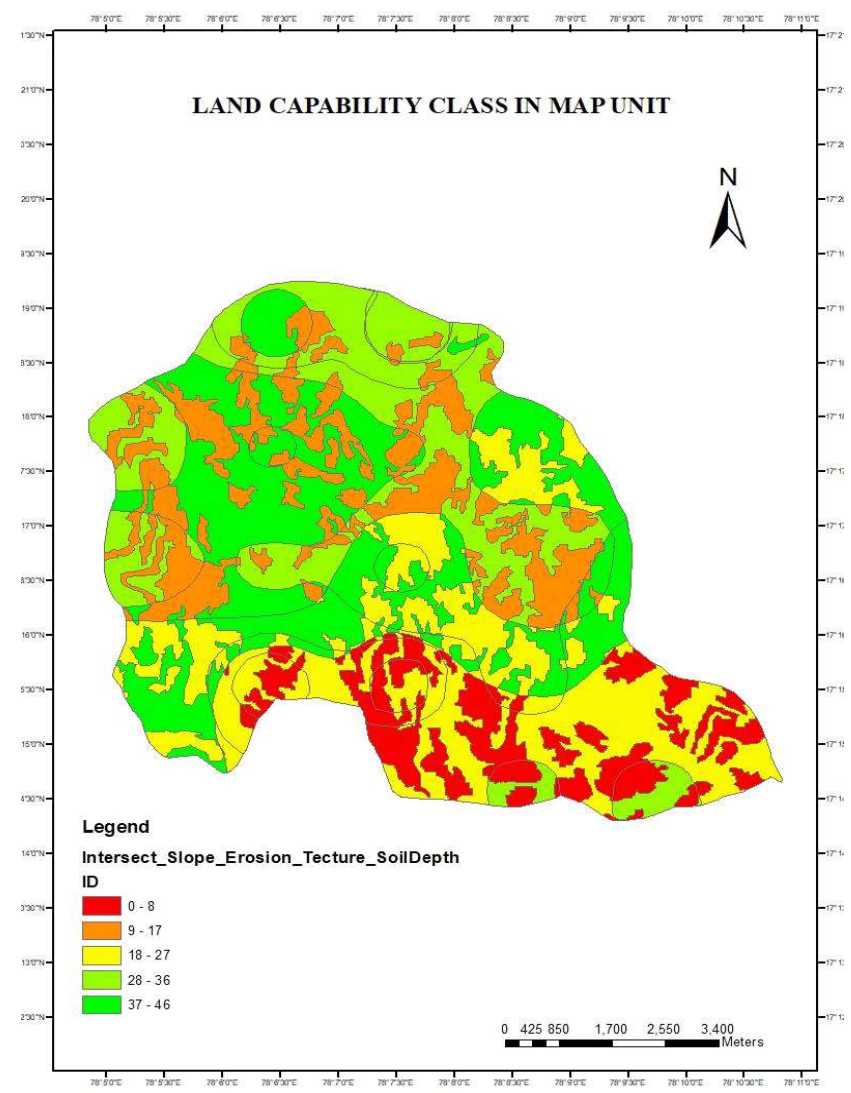

Fig. 7. Land capability class in map unit of Chevella Block
1. The information that was gathered at the village level for few parameters were done through PRA i.e., Public Rural Appraisal. It acted as a major tool for information at this micro level. The information that was obtained had fair better results than the interpolation techniques. As $100 \%$ area sampling cannot be done as there is limitation of samples and interpolation techniques fail in some cases because the soil and earth pattern changes abruptly. So, the PRA techniques was chosen to incorporate the public opinion and for mapping the area more appropriately.

2. This study if conducted at village level and done with proper techniques and analysis then it could be a very important tool for policy making and research purposes.

3. Data availability and time constrain for the collection of data lead to the consideration of only broad parameters and the other sub parameters could not be considered in detail.

4. Study done with more intensity, public interaction and actual analysis at sufficient grid distance could give perfect results.

5. Dissemination of the information: the information that has been collected or estimated at different level does not reach the grass root level but through the Web service all the information can be accessed at the ground level and this village has a computer center with a technician to assist the village from the government.

6. Frequent updating of the information at the village level would increase the efficiency of the process for future use and to maintain the land capability.

7. For better and enhanced study, the numerical weightage which gives precision to land class could be used specially in the Indian subcontinent.

8. Accuracy assessment: the accuracy assessment was not carried out for this study as the study area was remotely located and the revisit to the area in this time span was not feasible.

\section{CONCLUSION}

The results of this study clearly exhibit that due to many reasons that are prevailing in the environment the land is used more than its capability i.e., out of the total area 5836 hectares is over utilized. Thus, leading to increase in pressure on the land and with the increasing population growth the pressure would increase on them making land capability study more important. The 416 hectares of land if treated properly like the selection of crop and special attention at the time of seeding is given then this amount of land is good for agriculture. Whereas if the proper management of water, erosion, offset is taken care then 4643 
hectares of land could be put to best use without damaging the land. This in turn help us in conservation of the soil and water. Thus, this technique is mainly used for the soil and water conservation as the parameters that are considered are mainly of the condition of the soil which is very important for agricultural practices. In the study area the projects like Integrated Watershed Management Programme (IWMP) have benefited the cultivable land in a great extent. They are not only conserving the water, but the fertility of the surrounding land increased by the transportation of the soil from the dried-up lake. The intersection of scientific knowledge with the public knowledge at the village level proved to be of good importance.

\section{REFERENCES}

Gangopadhyay SK, Obi Reddy GP, Sarkar D, Srinivas CV, Khan QI and Krishnamurthy T 2010. Soil suitability evaluation using remotely sensed data and GIS: A case study from semi-arid tropics of India. International Journal of Geoinformatics 6(3): 3547.

Gurung S 2019 Land Capability Classification for Agriculture: GIS and Remote Sensing Approach: A Survey. In: Sarma H., Borah S., Dutta N. (eds) Advances in Communication, Cloud, and Big Data. Lecture Notes in Networks and Systems 31: 29-39
Jacobson RB, Chojnacki JA and Rueter JM 2007. Land Capability Potential Index (LCPI) for the Lower Missouri River valley: Scientific Investigations Report 2007-5256, Reston. US Geological Survey: 1-19

Kumar MR, Naveen M, Pravallika MS and Kumar S 2019. Variability and time series trend analysis of rainfall over Krishna District of Andhra Pradesh: A case study. International Journal of Recent Technology and Engineering 7(6C2): 720-726.

Mohan SC, Somra JS, Srivastava AK and Sharda VN 2007. Land capability and land suitability classification for land use planning. Soil Conservation and watershed Management 1: 89-118.

Prince SD, Becker-Reshef I and Rishmawi K 2009. Detection and mapping of long-term land degradation using local net production scaling: Application to Zimbabwe. Remote Sensing of Environment 113(5): 1046-1057.

Singer MJ 2020. Land capability analysis. In Landscape and Land Capacity, CRC Press, p 161-165

Singh PK 2000. land-use capability classification and topographical survey. Watershed Management (Design and Practices) 3: 14-24.

Solanki HK and Bishnoi B 1995. Planning and Designing of a Microwatershed in Udaipur district, B.E thesis, Rajasthan Agricultural University, p 125-141

Sujatha M, Satyanarayana T and Asadi SS 2019. Spatial distribution analysis on groundwater quality of Sarada River Basin, Visakhapatnam, AP India. International Conference on Advances in Civil Engineering 7(6C2): 747-751.

Tideman EM 2007. Watershed management: Guidelines for Indian conditions. Omega Scientific Publishers. p 204-207.

Received 10 October, 2021; Accepted 28 December, 2021 